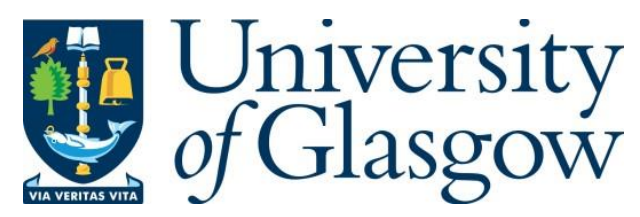

O'Brien, P., Lord, A. and Dembski, S. (2020) How do planners manage risk in alternative land development models? An institutional analysis of land development in the Netherlands. Land Use Policy, 91, 104409.

There may be differences between this version and the published version. You are advised to consult the publisher's version if you wish to cite from it.

http://eprints.gla.ac.uk/207524/

Deposited on: 14 January 2020

Enlighten - Research publications by members of the University of Glasgow http://eprints.gla.ac.uk 


\title{
How do planners manage risk in alternative land development models? An institutional analysis of land development in the Netherlands
}

\begin{abstract}
While risk is a key concern in property development, it tends to be discussed by planners only relative to the effects of regulatory planning on private sector risk. Yet planning encompasses a broad range of activities that go beyond its function of regulating private sector development. Despite active approaches to land development being commonly used across different planning contexts, frameworks for analysing public sector strategies to address risk are rarely discussed. We attempt to redress this deficit by investigating the actions of public sector development actors with regard to risk across three different land development models: public land development, land development by public-private partnership, and land readjustment. Using recent Dutch experience, we conduct an institutional analysis of each land development model in order to highlight the effects of alternative governance structures on risk as a particular transaction attribute, from the perspective of public sector planning. Our findings indicate the importance of highlighting the role of public risk in alternative models of land development where there may be a tendency to adopt institutional arrangements without due regard to this, and point to possible future applications of institutional analysis at the particular, rather than the general, level.
\end{abstract}

Key words: Risk; Land development models; the Netherlands; Institutional analysis; Transaction cost theory.

\section{Introduction}

Risk is generally discussed with respect to planning in terms of the ability of planning to reduce and contain risk in land and property markets (Neutze, 1987; Healey, 1992; Leishman et al, 2000). Yet this perspective considers planning only as a regulatory activity, whose relationship with risk is defined in terms of its relationship with the property development industry. Planning encompasses a much broader range of activities than just the regulation of private sector development, with associated consequences for the effect of planning on risk in land and property development, including the public risk associated with the purchase and sale of land by planning agencies (Allmendinger and Dunse, 2005; Adams and Tiesdell, 2010, 2013; Ploegmakers and Van der Krabben, 2012; Adams et al., 2016). Tiesdell and Allmendinger (2005) disaggregate planning into instruments that: 'shape' markets, by which is meant the setting of the context within which transactions occur, for instance through land-use plans; 'regulate' markets, for instance through development control mechanisms; 'stimulate' markets, by facilitating transactions using financial incentives such as tax breaks, as well as more interventionist approaches such as land assembly; and 'build capacity' in markets, through the raising of skills levels and the formation of public-private development partnerships. It follows that the relationship between planning and risk must be understood not only in relation to planning's regulatory role but with due consideration of the full range of tools and instruments it employs (Ploegmakers and Van der Krabben, 2012). 
This heterogeneous definition of planning is evidenced in the process of land development. The term 'land development' is used to describe the process by which land is acquired, assembled into an area suitable to be developed into a predetermined form, and serviced with sufficient infrastructure as to support new buildings (Needham and Verhage, 1998; Van der Krabben and Jacobs, 2013). Land development, which has been used synonymously with 'land management' (Van der Krabben and Jacobs, 2013), is intimately connected to the supply of land for development (Monk et al, 2013), and is distinguished within the overall development process from 'building development', which describes the process by which buildings are constructed on serviced plots (Needham and Verhage, 1998). Van der Krabben and Halleux (2011) regard land management strategies as a part of 'operational planning', as distinct from 'strategic planning' and 'regulatory planning'. Land development can be performed entirely by the private sector, but often takes place with public sector involvement. This may be due to a desire to achieve planning goals through land development or because certain characteristics of the land market can impede private sector development, such as fragmented landownership or development risks (Monk et al., 2013).

The uneven spatial distribution of land market characteristics impeding development has, combined with institutional contexts that have evolved over time, given rise to different models of land development, each involving a different combination of public and private action (Needham and Verhage, 1998; Van der Krabben and Halleux, 2011; Van der Krabben and Jacobs, 2013). Land development models have tended to be discussed on the basis of three objectives (Needham and Verhage, 1998; Van der Krabben and Halleux, 2011; Van der Krabben and Jacobs, 2013). First, to assemble land into an ownership structure and spatial arrangement conducive to the desired form of development. This addresses issues such as landowners being unwilling or unable to develop and land in fragmented ownership that does not match the shape of the desired new development. Second, to allow the public sector to recover planning and infrastructure costs necessitated by the development. Third, to capture the value increase that accrues due to a change in land-use or of building density permitted; what John Stuart Mill referred to as the 'unearned increment' (Fainstein, 2011). This last objective has been the subject of intense political debate in many countries, including the Netherlands (Van der Krabben, 2018).

Land development models always involve a trade-off between the achievement of planning goals and the level of risk assumed by the public sector in order to reach these. Yet, with a few exceptions (Hartmann and Spit, 2015; Savini, 2017), land development models have not generally been discussed in terms of the relative levels of public risk that they entail. Valtonen et al. (2017), in attempting such a task, examine how planning agencies engaging in public land development manage risk. As Valtonen et al. (2017, p.247) note, 'market risk control and its trade-offs with public interests are novel perspectives to approach this [public] land development strategy'. We would add that the interrelationships between market risk control and public interests are underexplored perspectives from which to view public-private relations in the land development process more generally. In this respect we are answering the call of Ploegmakers and Van der Krabben (2012, p.171): 'it is conjectured that different forms and combinations of public policy have different impacts on uncertainty reduction, although this has not yet been rigorously explored empirically'.

This paper aims to undertake an institutional analysis to investigate the effects of three distinct land development models, focusing on the prevalence of risk as a transaction attribute from the perspective of public sector planning. We examine the public land 
development model; the model of land development by public-private partnership; and the land readjustment model. These models were selected as being representative of three distinct modes of land development in which three discrete combinations of public and private action can be discerned, running in a continuum from more to less public involvement in land development. In this way we aim to broaden the scope of understandings of risk in relation to planning. While the models we consider are by no means practiced simultaneously within a range of planning contexts, they represent alternative combinations of public and private action that can be proposed as alternative governance structures in different planning contexts internationally, according to a process of institutional design. It is nevertheless useful to analyse the level of public risk borne in each model within the same national planning context.

There has been considerable interest in institutions and institutional change in planning research, reflecting the diversity of institutional approaches (Bolan, 1996; Healey, 1999; Buitelaar et al., 2007; Verma 2007; Dembski and Salet, 2010; Moroni, 2010; Sorensen, 2015; Salet 2018a, 2018b). Transaction cost theory (Alexander 1992, 2001b; Lai, 1994; Webster, 1998; Webster and Lai 2003; Buitelaar, 2004) is but one of the many frameworks of institutional analysis but is particularly suited to the question addressed in the paper, that is to highlight the role of public risk as a transaction attribute in each alternative land development model. Transaction cost theory can explain the need for land-use planning and development control, but is also useful in the identification of institutional arrangements that can raise the effectiveness of planning (Alexander, 2001b). We interpret our selected land development models as alternative governance structures that can be applied to the real estate development process, as per Alexander's (2001b, 2001c) framework for institutional analysis. Accordingly, we are undertaking a form of what Alexander (2001c) terms discriminating alignment, by comparing feasible forms of governance based on their effects in raising or lowering transaction costs. The novelty of our approach is that instead of seeking to lower transaction costs for all actors, our concern is to highlight the role of public risk as a transaction attribute in each alternative land development model.

This paper investigates land development models in the Netherlands, which offers an appropriate setting for this investigation for two reasons. First, it is a context in which the issue of public risk in land development has over the past decade come to the fore. Following the 2008 Global Financial Crisis, the heightened level of public risk attached to public land development was drawn attention to, as a number of municipalities found themselves with significant land holdings during a dramatic downturn in demand for new housing (Van der Krabben, Ploegmakers and Samsura, 2011). Second, and partly as a consequence of the first reason, a number of alternative land development models have been used in the Netherlands since the dominance of public land development began to decline during the early 1990s (Needham, 2007). The effects of the 2008 crisis on housing have only reinforced this search for alternative models. If the choice of land development model is generally path dependent, it has been suggested that the Netherlands may have reached a critical juncture, with a number of alternative land development models remaining in use until a new path is followed (Buitelaar and Bregman, 2016). As such, the time and place of the years following the crisis of 2008 in the Netherlands offer an especially salient window into the issue of public risk in the land development process.

The paper proceeds as follows. First, we discuss how planning has been influenced by theories and methods from economics, using this discussion to frame the conception of 
planning and markets as interrelated, rather than opposing, spheres (Alexander, 2001a; Adams and Tiesdell, 2010; Lord and O'Brien, 2017; Lord and Gu, 2019). Second, we consider the relationship between planning and risk, and the treatment of risk by planning agencies, noting the potential utility of institutional analysis to address these issues. Third, we apply an institutional analysis to three models of land development, as presently practiced in the Netherlands. Finally, in our concluding remarks we suggest that an underexplored and potentially profitable use of institutional analysis may lie in its application at the particular level of the singular governance structure or transaction attribute.

\section{Breaking the state-market dichotomy in analyses of planning}

Neoclassical approaches to the analysis of the effects of planning on land and property markets regard planning as a regulatory activity whose sole function is to control supply (see, for instance, Cheshire, 2009; Cheshire and Shepherd, 2005; Cheshire et al, 2014; Hilber and Vermeulen, 2012; Hilber, 2015). Within the neoclassical framework, land and property prices are determined by the interaction of supply and demand and the primary effect of the planning system is to regulate the supply of developable land. The measurable effect of the planning system within this framework is to raise prices by constraining supply against increasing demand. Justification for planning within the neoclassical paradigm comes from a welfare economics standpoint. Land and property markets are beset by inefficiencies and market failures arising from congestion, noise and other external effects unaccounted for by the market, leading to a need for correctives that come in the form of planning interventions (Evans, 2004), while the need to provide public goods requires a mechanism for the planned allocation of these (Klosterman, 1985; Moore, 1978).

This understanding of planning has been fundamentally questioned by New Institutional Economics (NIE) approaches, which break the state-market dichotomy. Planning research drawing on these approaches has long sought to situate planning as a necessary facilitator of land and property markets (Buitelaar, 2003, 2004; Buitelaar and Needham, 2007; Webster and Lai, 2003). Alexander (1992) argues that prohibitively high transaction costs in land and property markets corresponding to, for example, uncertainty regarding other developers' locational investments and external costs from neighbouring land uses, make necessary 'coordinative planning' in the form of land-use plans. Thus, echoing Coase (1937), hierarchical forms of organisation come into being where transaction costs are sufficiently high as to inhibit transactions taking place without their coordinative function.

Planning in this view is essential to the effective and efficient functioning of land and property markets (Allmendinger and Dunse, 2005; Adams and Tiesdell 2010; 2013; Adams and Watkins, 2014). Tiesdell and Allmendinger (2005) disaggregate planning into the numerous forms of activity undertaken by the state with the aim of achieving public policy goals in and through urban development, identifying the ability of plans and strategies to 'shape' markets, market regulation, market stimulus through planned interventions, and capacity building as key tools and instruments of the planning apparatus. Lord and O'Brien (2017) meanwhile argue that planning effectively performs the role of a 'market maker' for land and property markets, a catalysing intermediary that animates the development process. This challenge to the characterisation of planning as solely a regulatory activity with negative implications for land and property markets draws on a heterogeneous body of economic theory, 
encompassing NIE, welfare economics, behavioural economics and the social construction of markets (Adams and Watkins, 2014; Adams et al., 2016).

Where neoclassical analyses of the effects of planning focus on the measurable economic costs of supply constraints, NIE approaches focus on transaction costs, or those costs accrued in the reduction of uncertainty through the gathering of information (Buitelaar, 2004). Transaction cost theory has been applied to the land development process within the framework of institutional analysis, in which particular forms of governance, containing specific combinations of state-market interaction, are analysed in order to ascertain their effects on transaction costs (Alexander, 2007). Institutions in this approach are commonly defined as formal and informal rules of the game that form an external context to the transactions under investigation (e.g. Buitelaar, 2004) as opposed to more dynamic sociological definitions (see for an extensive discussion of institutional approaches Dembski and Salet, 2010). Most theorists in this strand of institutional analysis have an instrumental understanding of institutions, which is expressed in the idea that institutions can be designed based on a better understanding of the transactions of a particular market (Alexander, 2001c, 2005).

Empirical applications of transaction cost theory to planning have taken the form of institutional analyses of the development process in particular instances. As much as some NIE theorists focus on its general applicability (for instance Schotter, 1981), it is as a partial explanation that the NIE has been applied in planning and property development (Needham et al, 2011). Two such examples are Alexander's (2001c) institutional analysis of the Israeli system of land-use planning and development control, and Buitelaar's (2004) institutional analysis of the land development process in the Netherlands. Both authors take a similar approach, dividing the development process into stages and analysing the transactions that occur at each stage, their involved parties and their associated transaction costs. The purpose of this analysis is to enable what Williamson (1999) calls 'remediability': the comparison and selection of a set of institutional rules or governance structures on the basis of their effectiveness in achieving a particular public policy.

\section{Planning and risk}

Planning must deal with a variety of risks related to development, including disaster risk in the international development field (Wamsler, 2006) and flood risk in land allocations (Van Herk et al, 2011). Our concern is with financial risk associated with the development process. Risk is a key facet of the development process and the property development industry is centrally concerned with risk management in the conversion of development potential into profit (RICS, 2008). Whereas uncertainty denotes an inability to assign a probability to one among a range of outcomes, risk refers to the measurable probability of a particular negative outcome occurring. The conversion of uncertainty into risk is an important function of markets (Van der Krabben, 1995), but is less closely associated with hierarchical forms of organisation, such as planning. Where planning is considered with regard to its effect on risk in the development process it is generally from the perspective of the risks that planning imposes on developers and, correspondingly, of what planning can do to lower levels of risk for developers (Mayo and Sheppard, 2001; Malpezzi and Wachter, 2005; Ball, 2011). 
Yet, as noted in Section 2, this regulatory function is but one of a range undertaken under the banner of planning (Adams and Tiesdell, 2010, 2013). Adams and Tiesdell (2013, p.279), discuss the 'risk-reducing actions' that the public sector can take with regard to private development using a broader understanding of what constitutes planning, including the delivery of accurate market information, the provision of policy stability, the implementation of demonstration projects and place management initiatives. Similarly, Adair et al (1998, p.16), in the context of regeneration, point to the ability of the public sector to build confidence in the market by engaging in such activities as providing a guaranteed minimum standard of infrastructure, ensuring clarity in policies and processes, targeting initiatives, using simplified planning processes, and land assembly.

In explaining how risk is accounted for in decision-making, neoclassical economics uses expected utility theory, while behavioural economics has proposed prospect theory (Kahneman and Tversky, 1979). We explore the role of institutions and, specifically, transaction cost theory, as an alternative to these. Institutions are a means to reduce uncertainty and thereby raise the reliability of our expectations (Verma, 2007), while transactions in the land development process involve significant, long-term commitments that are subject to a high degree of uncertainty (Alexander, 2007). Accordingly, institutional design has been proposed as a means to identify those governance structures that reduce transaction costs, of which uncertainty is a significant component, for all participating actors (Alexander, 2001c). Yet investigations into institutional change have found that institutional design cannot always explain how institutions are selected in given empirical contexts (Buitelaar et al., 2007, 2014). An alternative explanation that has been offered is that of 'punctuated equilibrium', in which institutional continuity is path dependent, but where institutional change occurs at critical junctures (Sorensen, 2017). Buitelaar and Bregman (2016) argue that Dutch planning may presently be at just such a critical juncture, following a prolonged period of crisis and recession.

Our investigation adopts the form of institutional analysis, in which alternative forms of governance are compared for their relative suitability for a particular market process. Institutional analysis is undertaken to inform institutional design, which Alexander (2007, p.49) defines as the devising and realisation of rules, procedures and organisational structures that will enable and constrain behaviour and action so as to accord with held values, achieve desired objectives, accomplish set purposes or execute given tasks'. The purpose of this paper is to use transaction cost theory to inform an institutional analysis that draws attention to distributions of risk between public and private actors in alternative land development models.

Transaction cost theory identifies attributes of transactions that may lead to distorted market outcomes and focuses on how these attributes affect how markets work. Alexander (2001b), drawing on Williamson (1999), identifies transaction attributes that affect transaction costs due to their propensity to expose market participants to various hazards, among which uncertainty and risk are prominent. Asymmetric distributions of information regarding, for instance, the development potential of a site or the strategies of other market actors can lead to the hazard of opportunistic behaviour and raise transaction costs for some participants. Similarly, moral hazards can arise where risks can be shifted to other market actors. Transaction costs also arise where transactions are interdependent and repetitive, where there is the hazard that 'lock-in' can occur and market entry costs are raised. Risk and uncertainty thus represent a key issue within planning that is addressed by transaction cost 
theory, but which has not been the focus of institutional analyses of planning and development.

\section{The effects of alternative land development models practiced in the Netherlands on public risk}

We follow the approach outlined in Section 3 that has been used by Alexander (2001c) in the case of the Israeli planning system and by Buitelaar (2004) to examine the development process in the Netherlands. We adapt this approach, however, to analyse the effects of alternative land development models on a particular transaction attribute (that of risk and uncertainty) from the perspective of one party in the development process (the public sector). This research strategy allows us to examine each model as it is practiced within the same legal and national policy context for planning. The selection of the Netherlands is due to its accommodation of each of these land development models within a single such context, as well as its being a planning context in which an awareness of public sector risk in planning has been raised over the past decade, following the effects of the Global Financial Crisis of 2008 (Valtonen et al., 2017). The analysis has implications for planning elsewhere, however, to the extent that its primary purpose is to address alternative land development models that are, or have the potential to be, applied in different planning contexts.

Our analysis of each land development model takes the form of a description of how each model operates presently in the Netherlands followed by an analysis of the how transaction costs are raised or lowered according to hazards associated with risk and uncertainty with respect to the public sector. Each land development model we investigate is set out alongside its purpose, mode of land assembly, incidence within Dutch planning, the transaction costs particular to the model, and allocation of risk between public and private sector agents, in Table 1.

The study is informed by ten semi-structured interviews with academics and actors from the planning and property development industries, supplemented with a review of the planning literature relating to each model. Interviewees were selected on a non-statistical, purposeful basis, intended to cover both analytical and practice perspectives. Interview data was analysed thematically, within the context of a largely deductive investigation. This was done in order to avoid any tendency to systematically verify preconceived opinions on the part of the authors. 


\section{Table 1}

Alternative land development models. Source: partly derived from Van der Krabben and Jacobs (2013).

\begin{tabular}{|c|c|c|c|c|}
\hline $\begin{array}{l}\text { Land } \\
\text { development } \\
\text { model }\end{array}$ & Purpose & $\begin{array}{l}\text { Incidence within } \\
\text { Dutch planning }\end{array}$ & $\begin{array}{l}\text { Transaction costs in } \\
\text { which public risk is } \\
\text { raised }\end{array}$ & $\begin{array}{l}\text { Risk allocation between } \\
\text { public and private sectors }\end{array}$ \\
\hline $\begin{array}{l}\text { Public land } \\
\text { development }\end{array}$ & $\begin{array}{l}\text { To deliver new } \\
\text { development in } \\
\text { line with planning } \\
\text { goals while } \\
\text { recovering } \\
\text { infrastructure } \\
\text { costs and some } \\
\text { surplus value. }\end{array}$ & $\begin{array}{l}\text { 'Traditional' mode of } \\
\text { land development in } \\
\text { the Netherlands, } \\
\text { dominant between } \\
\text { World War Two and } \\
\text { the mid-1990s. }\end{array}$ & $\begin{array}{l}\text { Project conception; land- } \\
\text { use plan preparation; land } \\
\text { acquisition for full } \\
\text { development site; } \\
\text { procurement of } \\
\text { consultancy and } \\
\text { construction services. }\end{array}$ & $\begin{array}{l}\text { Majority of risk lies with } \\
\text { public sector. Public sector } \\
\text { bears long-term risk of land } \\
\text { development; private sector } \\
\text { bears shorter-term risk of } \\
\text { building development. }\end{array}$ \\
\hline $\begin{array}{l}\text { Land } \\
\text { development } \\
\text { by public- } \\
\text { private } \\
\text { partnership }\end{array}$ & $\begin{array}{l}\text { To 're-insert' a } \\
\text { specific area into } \\
\text { the property } \\
\text { market in a way } \\
\text { that achieves } \\
\text { planning goals } \\
\text { usually relating to } \\
\text { urban } \\
\text { regeneration, } \\
\text { and/or to share } \\
\text { risk between } \\
\text { public and private } \\
\text { parties. }\end{array}$ & $\begin{array}{l}\text { Originally used in } \\
\text { urban regeneration, } \\
\text { but since used in } \\
\text { different forms as } \\
\text { adaptations to VINEX } \\
\text { programme and focus } \\
\text { on brownfield } \\
\text { development. }\end{array}$ & $\begin{array}{l}\text { Negotiated project } \\
\text { conception; negotiated } \\
\text { land purchase and/or } \\
\text { pooling arrangements; } \\
\text { contract preparation for } \\
\text { joint ventures; negotiated } \\
\text { land-use plan preparation; } \\
\text { cost recovery. }\end{array}$ & $\begin{array}{l}\text { Risk is shared, but majority } \\
\text { of risk lies with public sector. } \\
\text { Public involvement in land } \\
\text { assembly and infrastructure } \\
\text { provision lowers risk for } \\
\text { subsequent private } \\
\text { investment. }\end{array}$ \\
\hline $\begin{array}{l}\text { Land } \\
\text { readjustment }\end{array}$ & $\begin{array}{l}\text { To enable } \\
\text { development of a } \\
\text { defined area by } \\
\text { 'reparcelisation' of } \\
\text { land. }\end{array}$ & $\begin{array}{l}\text { National experiment } \\
\text { with land readjustment } \\
\text { in the Netherlands, } \\
\text { introduced in } 2014 .\end{array}$ & $\begin{array}{l}\text { Project promotion; } \\
\text { facilitation of readjustment } \\
\text { plan; land-use plan } \\
\text { adjustment; cost recovery. }\end{array}$ & $\begin{array}{l}\text { Risk is shared between } \\
\text { landowners. Public risk of } \\
\text { failure to deliver new } \\
\text { development. Public sector } \\
\text { takes on risk where public } \\
\text { infrastructure is built. }\end{array}$ \\
\hline
\end{tabular}

\subsection{Public land development}

Public land development involves the acquisition of land and its servicing with infrastructure by the public sector before being divided into plots and sold to private sector developers. The degree of risk assumed by the public sector in public land development is substantial, and that taken on by private sector developers is relatively minimal (Needham and Verhage, 1998; van der Krabben and Jacobs, 2013; Valtonen et al, 2017). Public land development was, for half a century, the dominant model of land development in the Netherlands, with municipalities generally adopting an 'active', development-led land policy. By the mid-1990s, persistently low interest rates, a relaxation of mortgage lending, and a rapid increase in the number of households, all combined to raise demand for owner-occupied housing. Alongside this, municipalities' traditional approach, of setting sale prices for serviced plots to enable cost recovery plus a small profit, was contested by the argument that a greater level of profit would enable the provision of better public facilities. This argument was to be facilitated by deliberately slowing the supply of land in order to raise its price and was put into practice in the national urbanisation strategy known as VINEX during the 1990s. The increase in prices 
for developable land drew interest from housebuilders, as the development gains began to exceed the risks of land development (Needham, 2007). Since the 1990s the share of new housing delivered through an active land policy has declined rapidly against completions delivered by public-private partnerships, though public land development continues to be practiced at a smaller scale (Tennekes, 2018).

Since public land development requires the municipality to acquire and assemble all land for development, the great majority of risk in this transaction is assumed by the public sector. Pre-emption rights and compulsory purchase are viable in land assembly (providing a landuse plan is in place), thus minimising risk for the municipality as part of the land purchase transaction, though these are only sparingly used, being viewed as complex and timeconsuming (Korthals Altes, 2014). As per Alexander (2001b), the most important factor in land acquisition is the land value, which is representative of the development potential of the site, which in turn is heavily dependent upon land-use change on neighbouring sites and in the surrounding area. In the Netherlands land-use plans are not generally prepared for the whole of a municipality but, under public land development, sites are typically of a large scale, such that they dominate the land-use pattern of the wider area, thereby lowering the risk of neighbourhood effects. The municipality's responsibility for project conception and development plan preparation, while generating transaction costs, creates information on development potential and provides certainty in determining neighbourhood effects. While the municipality's control over land-use designations and small-scale infrastructure in the wider area should theoretically give it an information advantage over private developers with whom it competes for land, this is not presently widely exploited as public land development at scale has been usurped by land development by public-private partnership.

Under public land development the preparation of land for development and parcelisation is undertaken entirely by the municipality, requiring procurement of contractor and consultant services. These transactions tend to be durable, as the development process can take several years, and repetitive, where municipalities are keen to use trusted service providers. This raises the issue of 'asset specificity', in which assets are not substitutable and market actors become interdependent (Alexander, 2001b), and may raise transaction costs related to the coordination of market participants. Opportunism on the part of some actors may also arise where procurement is insufficiently open. Similar issues can arise at the land disposal stage, where municipalities prefer to use large-scale developers. The preference for particular private firms does, however, have the advantage of causing public and private sectors to work together to reduce risk in the property market.

\subsection{Land development by public-private partnership}

The transition from a land policy focused primarily on public land development to one focused on public-private development was triggered by a shift in land ownership from the 1990s onwards as municipalities were unable to acquire land for development as they had done previously, as noted in Section 4.1. Yet this inability to acquire land has not led Dutch municipalities to adopt the passive position of local authorities in many other countries, by preparing a land-use plan that developers must adhere to, thereby lowering their transaction costs in development conception and land acquisition. Instead, the longstanding obligation of municipalities to not only supply land but to deliver development (Van der Krabben and Jacobs, 2013) has resulted in the formation of public-private development partnerships, as 
municipalities have sought a means by which to continue their active land policy without necessarily undertaking public land development. While transaction costs are raised by the need for negotiation, the tendency towards interdependence, and the possibility of information asymmetries working in favour of the private developer, risk of project failure is pooled between public and private sectors. Two models of public-private partnership are prevalent. In the building claim model private landowners sell their land to the municipality on the condition that they will receive in return the option to buy, at an agreed price, serviced plots. In the joint venture model, the municipality and the private landowner pool their land within a private company and develop it together, thereby eliminating the land disposal stage of development for the municipality.

Land assembly entails either the public purchase of land from landowners, in the building claim model, or the transfer of ownership into a joint venture. In the case of the building claim model negotiations over price take place, as the land transaction is not straightforward, while in the joint venture model contracts must be drawn up to incorporate the newly created venture. In the building claim model risk is pooled only if the transfer of ownership contract between the landowner and the municipality guarantees that the landowners will exercise their option to buy. In the joint venture model risk is pooled according to the proportions in which land and investment are pooled. In both cases negotiations take place over the layout of the site and the necessary infrastructure. Landowners are keen to be involved in plan preparation because the plan gives them certainty and because it represents an opportunity to raise the value of their development. Negotiated plans thus raise transaction costs for all parties and may increase levels of uncertainty where information asymmetries exist. Yet their effect on the overall development is to lower risk by guaranteeing what can be built and they may also raise the value of the development.

Negotiations also usually take place over the costs of infrastructure, which are generally agreed by private contract though which may be recovered by public law where the municipality has a land-use plan and contribution plan already in place. Both municipalities and private developers prefer to negotiate infrastructure costs using private contracts, in spite of this serving to increase their transaction costs and their associated project risks. While municipalities are thus inclined because they are limited by public law as to the type and scale of costs they can impose via contribution plans, private developers value the control over the scheme and its associated costs that negotiation allows. As noted in Section 4.1, part of the reason why municipalities assume the substantial risks associated with public land development is that it brings the reward of value capture, alongside the achievement of planning goals. While development by public-private partnership lowers the overall project risk for the municipality, it also lowers the scope for value capture, which must be shared with private actors. Interestingly, the shift in geographical focus of development from greenfield to brownfield sites that has occurred with the transition from public to publicprivate development has also affected the attitude of municipalities with regard to value capture.

'The other reason that municipalities don't care so much about surplus value is that with the shift to brownfield development there's not so much surplus value to be made. And I think that one of the big issues for planning in the Netherlands is that, if we continue to shift to brownfield development, the problem will not be so much that there is not enough surplus value, but that there won't be enough profitable developments 
anymore. That's a discussion that isn't taking place yet, but when I speak to people in city governments, they all agree.' (Interview, planning academic.)

Given that municipalities are responsible for supplying a sufficient quantity of housing as to meet prevalent need, when they opt to deliver this through partnership with private developers, via negotiated plans, they imbue their negotiations with the risk that, should they fail, housing supply goals will not be met. Partially counteracting this responsibility is the upper hand that municipalities hold with regard to land-use plan approval. The approval of the land-use plan for project development is a sovereign task, therefore as much as the plan can be negotiated by public and private actors, plan approval can be used as a bargaining chip by municipalities in negotiation, raising the possibility of moral hazard.

\subsection{Land readjustment}

Land readjustment - sometimes termed reparcelisation, replotting, land pooling, or land consolidation - is a model of land development that aims primarily to create plot layouts suitable for development but is also used to facilitate land assembly as a stage in land development (Dietrich et al, 1993). Where land development is inhibited by a sub-optimal configuration of plots, land readjustment allows for plots to be rearranged and/or consolidated in order to facilitate their redevelopment into more economically or socially profitable use. This is achieved by the pooling of land from a given number of plots and its redistribution among landowners, who either gain more value than they had prior to the exercise or are compensated for value lost. Redistribution can be according to either plot values or sizes. Land readjustment is thus a land development model that turns not on the public ownership and/or development of land but on the adjustment of property rights over the private ownership and use of land. The use of land readjustment in the Netherlands is longstanding, having been applied to agricultural land there since 1924 (Needham, 2007), but land readjustment has only recently been experimented with in urban areas, following central government's establishment of a committee to explore its potential application in 2013 and has been included as an instrument in the forthcoming Environment and Planning Act. In the proposed Dutch model, land readjustment is a voluntary exercise involving negotiation among landowners, in which risk and reward are thus shared among landowners according to land or capital invested.

That urban land readjustment in the Netherlands is a voluntary exercise undertaken by landowners (usually in partnership with private developers in the guise of an 'implementation agency') might imply that transaction costs associated with project conception are zero for the municipality. In fact, around ninety of the hundred cases completed in the first year of the pilot programme involved municipalities taking a lead role at an early stage in the process (interview, Land Registry Senior Officer). This inevitably raises transaction costs for the municipality but may ultimately lower the risk that insufficient housing is delivered there, reflecting the municipality's role in housing delivery.

A fundamental feature of land readjustment is that land acquisition is absent from, but land assembly is facilitated by, the model. Indeed, transaction costs associated with land assembly issues of the first mover problem, the free rider problem and the holdout problem are addressed by land readjustment (Lord and O'Brien, 2017). Transaction costs for land acquisition are therefore zero, though transaction costs for land assembly can be extremely 
high, in spite of this being an aim of the model, because of the voluntary nature of urban land readjustment in the Netherlands. Where land readjustment is mandatory, as is the case in Germany, the readjustment plan has been formulated independently of the owners by a land readjustment committee operating at arm's length from local government, and landowners receive a new plot of land in the readjustment plan whether they agree to the exercise or not (Davy, 2007; Muñoz Gielen, 2016). In the Netherlands it is the landowners who must negotiate amongst themselves in order to draw up the readjustment plan. Where there is clear potential for land value uplift for all landowners following the implementation of the plan, negotiation may prove to be relatively straightforward, but where the existence of such potential is in doubt, the redevelopment may be obstructed.

'The transaction costs are a pretty interesting feature in this deal making scenario, because if you have a situation in which you can create a lot of new value, it's not so difficult to make a deal with each other. If you have a case in which there is a lot of negative value, the deal won't happen, unless there are other reasons, such as social aims ... The interesting part is that you have cases that are hanging in the balance; they are a little bit negative or a little bit positive, they are around zero, and by lowering transaction costs you can make them possible. For instance, by lowering taxes or you can say, well we have a law which says that if you develop real estate you have to pay a certain amount of money towards infrastructure, like public spaces, but if you make a deal that achieves social aims [already], so that there is less empty real estate or the area is safer, you won't have to pay towards public works. Local government will pay itself.' (Interview, Land Registry Senior Officer.)

In those cases where development potential hangs in the balance, the lowering of transaction costs via the municipality bringing landowners and developers together and contributing to the exploration of development options may encourage development. This points to the market supportive role played by the municipality in urban land readjustment in the Netherlands, wherein it promotes projects, facilitates landowner negotiations, adjusts land-use plans where necessary and may implement infrastructure. Ultimately though, the municipality takes a passive, rather than its usual active, role in the development process.

'It's a process so [landowners] need guidance in this process, they often need the municipality to give approval to the plans, and also it's not their core business. Their business is not urban development, it's making cars or whatever, so they're not experts, and they have to do it in their spare time, so they need help. Otherwise it won't happen, because it's very complicated, [in terms of the] deal making.' (Interview, Land Registry Senior Officer.)

Where development gains are small but there are social gains to be made, the role of the public sector can expand to lower developer contributions to infrastructure investments. Where significant surplus value is created by land development, agreements between the public and private sector can be easily arrived at. But where little or no surplus value is generated but significant public gains can be made, development that would not otherwise proceed can be stimulated by public sector investment. The public sector thus maintains its role as the animator of development where it considers the potential for the achievement of planning goals to be attractive.

The municipality also maintains an active role in cost recovery and land-use plan adjustment. The costs of redevelopment are paid for by the implementation agency but must be agreed by the municipality, either by private contract or public law, in the latter case as 
part of a development contribution plan. Where costs are agreed by private contract, there is the possibility that the landowners can negotiate to reduce these, though in such a circumstance the municipality is able to veto the redevelopment by refusing to grant a necessary change to the land-use plan.

\section{Concluding Remarks}

This paper applied an application of institutional analysis drawn from Alexander's (1992, 2001 b, 2001c) transaction cost theory of land-use planning to the specific aim of investigating the effects of alternative land development models (or governance structures in Alexander's terminology) on risk as a transaction attribute. Taking our selected development models in turn, we discussed how each lowered or raised levels of risk and uncertainty for transactions in the land development process from the perspective of the public sector. We undertook our investigation using three land development models - public land development, land development by public-private partnership, and land readjustment - as they are presently practiced within the same legal and policy context - the Netherlands - in order to control for exogenous variables that differ across national contexts. Although our investigation focuses on a single country, our approach of comparing alternative land development models within a single piece of institutional analysis, as well as our use of institutional analysis to examine the effects of different governance structures on a particular transaction attribute, are novel adaptations of existing research in institutional analysis.

Where empirical studies employing transaction cost theory have been limited by the difficulty of gathering quantitative data on transaction costs, the utility of institutional analysis may be in its heuristic value, in the sense that the identification of transaction costs can enable us to compare alternative means of process coordination or governance (Buitelaar, 2004). Given that our ability to study transaction costs appears to be limited to their identification and comparison, it follows that a useful avenue for the further application of institutional analysis might be found in studying the particular, rather than the general. Future applications of institutional analysis in planning might therefore focus on particular planning instruments or on the prevalence of particular transaction attributes in the application of these.

The Global Financial Crisis has raised awareness of the significant public sector risks in land development, which has affected all forms where the public sector was the major landowner. This increased awareness of public risk has led to a reassessment of the role of the state in land development in the Netherlands, and a search for alternative models in which public risks can be minimised (van der Krabben and Jacobs, 2013). The suggestion of Buitelaar and Bregman (2016) that Dutch planning, following the 2008 crisis, may be at a critical moment for institutional change points to the potential importance of the role played by institutional design against a background of institutional path dependence. This paper highlights the importance of institutional analysis as a means of recognising and understanding the role played by planning institutions in allocating risk between public and private market participants in the land development process. It is argued that institutional analysis can in this way be used by public sector planning agencies to inform the generation of institutional designs that aim specifically to minimise public risk, alongside the conventional aim of institutional design, to lower transaction costs (and therefore uncertainty) for all stakeholders. 


\section{References}

Adair, A., Berry, J., Deddis, W., Hirst, S. and McGreal, S. 1998. Accessing Private Finance: The Availability and Effectiveness of Private Finance in Urban Regeneration. Research Report. RICS, London.

Adams, D. and Tiesdell, S. 2010. Planners as market actors: rethinking state-market relations in land and property. Planning Theory and Practice 11(2), 187-207.

Adams, D. and Tiesdell, S. 2013. Shaping Places: Urban Planning, Design and Development. Routledge, Abingdon.

Adams, D. and Watkins, C. 2014. The Value of Planning. RTPI Research Report No. 5. RTPI, London.

Adams, D., O'Sullivan, M., Inch, A., Tait, M., Watkins, C., Harris, M. 2016. Delivering the Value of Planning. RTPI Research Report No. 15. RTPI, London.

Adams, D., Dunse, N. and White, M. 2005. Conceptualising state-market relations in land and property: the growth of institutionalism - extension or challenge to mainstream economics? In: D. Adams, C. Watkins and M. White (Eds.), Planning, Public Policy and Markets. Blackwell, Oxford, pp. 37-55.

Alexander, E.R. 1992. A transaction cost theory of planning. Journal of the American Planning Association 58(2), 190-200.

Alexander, E.R. 2001a. Why planning versus markets is an oxymoron: asking the right question. Planning and Markets 4(1), 1-17.

Alexander, E.R. 2001b. A transaction cost theory of land-use planning and development control: towards the institutional analysis of public planning. Town Planning Review 72(1), 45-75.

Alexander, E.R. 2001c. Governance and transaction costs in planning systems: a conceptual framework for institutional analysis of land-use planning and development control: The case of Israel. Environment and Planning B: Planning and Design 28(5), 755-776.

Alexander, E.R. 2007. Institutionalist perspectives on planning: Why? Where? How? In: N. Verma (Ed.) Institutions and Planning. Elsevier, Oxford, pp. 37-60.

Allmendinger, P. and Dunse, N. 2005. Perspectives on the role of UK planning in land and property markets. Working Papers in Real Estate and Planning, 14/05. University of Reading, Reading.

Ball, M. 2011. Planning delay and the responsiveness of English housing supply. Urban Studies 48(2), 349-362.

Bolan, S. 1996. Planning and institutional design. In: S.J. Mandelbaum, L. Mazza and R.W. Burchell (Eds), Explorations in Planning Theory. Center for Urban Policy Research, New Brunswick, NJ, pp. 497-513.

Buitelaar, E. 2003. Neither market nor government: comparing the performance of user rights regimes. Town Planning Review 74(3), 315-330. 
Buitelaar, E. 2004. A Transaction-cost Analysis of the Land Development Process. Urban Studies 41(13), 2539-2553.

Buitelaar, E., Needham, B. 2007. Property rights and private initiatives: an introduction. Town Planning Review 78(1), 1-8.

Buitelaar, E., Lagendijk, A. and Jacobs, W. 2007. A theory of institutional change: illustrated by Dutch city-provinces and Dutch land policy. Environment and Planning A 39(4), 891-908.

Buitelaar, E., Galle, M. and Sorel, N. 2014. The public planning of private planning: an analysis of controlled spontaneity in the Netherlands. In: D.E. Andersson and S. Moroni (Eds.), Cities and Private Planning: Property Rights, Entrepreneurship and Transaction Costs. Edward Elgar, Cheltenham, pp. 248-268.

Buitelaar, E. and Bregman, A. 2016. Dutch land development institutions in the face of crisis: Trembling pillars in the planners' paradise. European Planning Studies 24(7), 1281-1294.

Cheshire, P., Nathan, M. and Overman, H.G., 2014. Urban Economics and Urban Policy: Challenging Conventional Wisdom. Edward Elgar, Cheltenham.

Coase, R.H. 1937. The nature of the firm. Economica 4(16), 386-405.

Davy, B. 2007. Mandatory happiness? Land readjustment and property in Germany. In: Y.H. Hong and B. Needham (Eds.), Analyzing Land Readjustment: Economics, Law and Collective Action. Lincoln Institute of Land Policy, Cambridge, Mass., pp. 37-55

Dembski, S. and Salet, W. 2010. The transformative potential of institutions: how symbolic markers can institute new social meaning in changing cities. Environment and Planning $A$, 42(3), 611-625.

Dieterich, H., Dransfeld, E. and Voss, W. 1993. Urban Land and Property Markets in Germany. UCL Press, London.

Fainstein, S. 2011. Land value capture and justice. In: G.K. Ingram and Y.-H. Hong (Eds.) Value Capture and Land Policies. Lincoln Institute of Land Policy, Cambridge, Mass., pp. 2140.

Hartmann, T. and Spit, T. 2015. Dilemmas of involvement in land management: comparing an active (Dutch) and a passive (German) approach. Land Use Policy 42, 729-737.

Healey, P. 1992. Development plans and markets. Planning Practice and Research 72(2), 13-20.

Healey, P. 1999. Institutionalist analysis, communicative planning, and shaping places. Journal of Planning Education and Research 19(2), 111-121.

Hong, Y.-H. 2007. Assembling land for urban development: issues and opportunities. In: Y.H. Hong and B. Needham (Eds.) Analyzing Land Readjustment: Economics, Law and Collective Action. Lincoln Institute of Land Policy, Cambridge, Mass. pp. 3-34.

Kahneman, D. and Tversky, A. 1979. Prospect theory: an analysis of decision under risk. Econometrica 47(2), 263-292.

Korthals Altes, W.K. 2014. Taking planning seriously: compulsory purchase for urban planning in the Netherlands. Cities 41, 71-80. 
Lai, L.W.C. 1994. The economics of land-use zoning: a literature review and analysis of the work of Coase. The Town Planning Review 65(1), 77-98.

Leishman, C., Jones, C. and Fraser, W. 2000. The influence of uncertainty on housebuilder behaviour and residential land values. Journal of Property Research 17(2), 147-168.

Lord, A.D., O'Brien, P., Sykes, O. and Sturzaker, J. 2015. Planning as 'market maker': How planning is used to stimulate development in Germany, France and the Netherlands. RTPI Research Report No. 11. RTPI, London.

Lord, A.D. and O'Brien, P. 2017. What price planning? Reimagining planning as 'market maker'. Planning Theory and Practice 18(2), 217-232.

Lord, A.D. and Gu, Y. 2019. Can the market be tamed? A thought experiment on the value(s) of planning. Environment and Planning A: Economy and Space 51(1), 11-24.

Malpezzi, S. and Wachter, S. 2005. The role of speculation in real estate cycles. Journal of Real Estate Literature 13(2), 141-164.

Monk, S., Whitehead, C., Burgess, G. and Tang, C. 2013. International Review of Land Supply and Planning Systems. Report to the Joseph Rowntree Foundation. JRF, London.

Muñoz Gielen, D. 2016. Proposal of land readjustment for the Netherlands: an analysis of its effectiveness from an international perspective. Cities 53, 78-86.

Moroni, S. 2010. An evolutionary theory of institutions and a dynamic approach to reform. Planning Theory 9(4), 275-297

Needham, B. 1997. Land policy in the Netherlands. Tijdschrift voor Economische en Sociale Geographie 88(3), 291-296.

Needham, B. 2007. The search for greater efficiency: land readjustment in the Netherlands. In: Y.-H. Hong and B. Needham (Eds.) Analyzing Land Readjustment: Economics, Law and Collective Action. Lincoln Institute of Land Policy, Cambridge, Mass., pp. 115-132.

Needham, B. and Verhage, R. 1998. The effects of land policy: quantity as well as quality is important. Urban Studies 35(1), 25-44.

Needham, B., Segeren, A. and Buitelaar, E. 2011. Institutions in theories of land markets: Illustrated by the Dutch market for agricultural land. Urban Studies 48(1), 161-176.

Neutze, M. 1987. The supply of land for a particular use. Urban Studies 24(5), 379-388.

Ploegmakers, H. and van der Krabben, E. 2012. Planning and uncertainty: how Dutch planners try to reduce uncertainty on the market for industrial properties. In: T. Hartmann and B. Needham (Eds.) Planning by Law and Property Rights Reconsidered. Ashgate, Farnham, pp. 171-188.

Royal Institution of Chartered Surveyors (RICS) 2008. Valuation Information Paper 12: Valuation of Development Land. RICS, Coventry.

Rodney, B. and Clark, P. 2000. Financing urban regeneration. City University Business School Real Estate Finance and Investment Research Paper No. 2000(4). City University, London. 
Salet, W. (Ed.) 2018. The Routledge Handbook of Institutions and Planning in Action. Routledge, New York.

Salet, W. 2018. Public Norms and Aspirations: The Turn to Institutions in Action. Routledge, New York.

Savini, F. 2017. Planning, uncertainty and risk: The neoliberal logics of Amsterdam urbanism. Environment and Planning A 49(4) 857-875.

Schotter, A. 1981. The Economic Theory of Social Institutions. Cambridge University Press, Cambridge.

Sorensen, A. 2015. Taking path dependence seriously: an historical institutionalist research agenda in planning history. Planning Perspectives 30(1), 17-38.

Sorensen, A. 2017. New institutionalism and planning theory. In: M. Gunder, A. Madanipour and V. Watson (Eds.) The Routledge Handbook of Planning Theory. Routledge, Abingdon, pp. 250-263.

Tennekes, J. 2018. Negotiated land-use plans in the Netherlands: A central instrument in Dutch 'active' and 'passive' land policy. In: J.-D. Gerber, T. Hartmann and A. Hengstermann (Eds.) Instruments of Land Policy: Dealing with Scarcity of Land. Routledge, Abingdon, pp. 101-113.

Tiesdell, S. and Allmendinger, P. 2005. Planning tools and markets: towards an extended conceptualisation. In: D. Adams, C. Watkins and M. White (Eds.) Planning, Public Policy and Property Markets. Blackwell, Oxford, pp. 56-76.

Valtonen, E., Falkenbach, H. and Van der Krabben, E. 2017. Risk management in public land development projects: comparative case study in Finland and the Netherlands. Land Use Policy 62, 246-257.

Van der Krabben, E. 1995. Urban Dynamics: A Real Estate Perspective. An Institutional Analysis of the Production of the Built Environment. PhD Thesis. Centre for Economic Research, Tilburg University, Tilburg.

Van der Krabben, E. 2018, A Dutch perspective on added value capture: how far can you go? In: J.-D. Gerber, T. Hartmann and A. Hengstermann (Eds.) Instruments of Land Policy: Dealing with Scarcity of Land. Routledge, Abingdon, pp. 70-73.

Van der Krabben, E. and Needham, B. 2008. Land readjustment for value capturing: a new planning tool for urban redevelopment. Town Planning Review 79(6), 651-671.

Van der Krabben, E. and Halleux, J.-M. 2011. Choosing the right land management strategy: innovations in land management tools. In: M. Tira, E. van der Krabben and B. Zanon (Eds.) Land Management for Urban Dynamics: Innovative Methods and Practices in a Changing Europe. Maggiole Editore, Milan, pp.50-59.

Van der Krabben, E. and Jacobs, H. 2013. Public land development as a strategic tool for redevelopment: reflections on the Dutch Experience. Land Use Policy 30, 774-783.

Van Herk, S., Zevenbergen, C., Ashley, R. and Rijke, J. 2011. Learning and action alliances for the integration of flood risk management into urban planning: A new framework for empirical evidence from the Netherlands. Environmental Science and Policy 14, 543-554. 
Verma, N. (Ed.) 2007. Institutions and Planning. Elsevier, Oxford.

Wamsler, C. 2006. Mainstreaming risk reduction in urban planning and housing: A challenge for international aid organisations. Disasters 30(2), 151-177.

Webster, C. 1998. Public choice, Pigouvian and Coasian planning theory. Urban Studies 35(1), 53-75.

Webster, C. and Lai, L.W.C. 2003. Property Rights, Planning, and Markets: Managing Spontaneous Cities. Edward Elgar, Cheltenham.

Williamson, O.E. 1999. Public and private bureaucracies: A transaction cost economics perspective. Journal of Law, Economics and Organization 15(1), 306-342. 